https://nv.nltu.edu.ua

https://doi.org/10.36930/40310417

ISSN 2519-2477 (online)

Article received 02.09.2021 $\mathrm{p}$.

Article accepted 09.09.2021 p.

$@ \bowtie$ Correspondence author

UDC 657.47.011.1

\title{
КАЛЬКУЛЮВАННЯ СОБІВАРТОСТІ ПРОДУКЦІї НА ХЛІБОПЕКАРСЬКИХ ПІДПРИЄМСТВАХ УКРАЇНИ
}

3'ясовано зміст поняття калькулювання собівартості виготовлення продукції. Встановлено особливості у побудові статей калькуляції на хлібопекарських підприємствах. Досліджено особливості основних методів калькулювання. Обгрунтовано причини, згідно з якими хлібопекарські підприємства не можуть використовувати однопередільний, позамовний та попередільний методи. Визначено основні проблеми під час використання цих методів і зазначено, в яких галузях промисловості їх варто застосовувати. Розглянуто особливості однопередільного методу калькулювання собівартості і наведено приклади підприємств, де його використовують. Встановлено об'єкт калькулювання позамовного методу. Обгрунтовано використання попередільного методу на підприємствах та у виробництвах з повторюваною й однорідною масовою продукцією. Встановлено, що найоптимальнішим для хлібопекарських підприємств можна вважати нормативний метод. Наведено його основні переваги та етапи застосування. Визначено основні етапи калькулювання нормативних витрат на хлібопекарських підприємствах. З'ясовано, як визначають потребу підприємства у сировині за рік. Наведено зразок звітної калькуляції, яку використовують для розрахунку фактичної собівартості виробленої продукції після завершення звітного періоду. Її особливістю $€$ те, що в такій калькуляції відображають водночас й втрати, які не передбачені у розрахунку планової собівартості виготовлення продукції.

Ключові слова: нормативний метод; калькуляція; собівартість виготовлення продукції; стаття витрат; фактичні витрати; нормативні витрати.

\section{Вступ / Introduction}

Система обліку виробничих витрат має стратегічне значення для хлібопекарських підприємств України. Підвищена увага до обліку витрат виробництва пов'язана із необхідністю врахування змін бізнес-середовища, що змушує хлібопекарські підприємства шукати нові підходи до вдосконалення цього процесу, опрацьовувати нові форми обліку виробничих витрат. У системі управління витратами хлібопекарських підприємств одна 3 ключових функцій належить калькулюванню собівартості виготовлення продукції. Собівартість виготовлення продукції, як об'єктивно економічна категорія, виражає у грошовій формі витрати на використані у процесі виробництва засоби і предмети праці, оплату праці тощо. Отже, собівартість виготовлення продукції показує обсяг витрат на виробництво продукції, які підприємство повинно відшкодувати для забезпечення безперебійного виробництва. Для забезпечення сталого розвитку хлібопекарських підприємств необхідно, передусім, удосконалювати систему управління витратами виробництва, зокрема, через удосконалення методики калькулювання собівартості виготовлення продукції.

Об'єкт дослідження - калькулювання собівартості виготовлення продукції.

Предмет дослідження - теоретико-методичні засади і практичні проблеми калькулювання собівартості виготовлення продукції на хлібопекарських підприєм- ствах України.

Мета роботи - з'ясувати теоретико-методичні засади калькулювання собівартості виготовлення продукції на підприємстві України та розробити практичні рекомендації з удосконалення процедури їх здійснення.

Для досягнення зазначеної мети визначено такі основні завдання дослідження:

- розглянути суть, види і форми калькулювання собівартості виготовлення продукції;

• з'ясувати теоретичне підгрунтя калькулювання собівартості виготовлення продукції;

- вивчити організацію і документальне відображення в обліку калькулювання собівартості виготовлення продукції на хлібопекарських підприємствах;

- дослідити способи вдосконалення калькулювання собівартості виготовлення продукції на хлібопекарських підприємствах.

Наукова новизна отриманих результатів дослідження - обгрунтовано теоретичні та методичні засади управління витратами за допомогою калькулювання собівартості виготовлення продукції на хлібопекарських підприємствах.

Практична значущість результатів дослідження визначено найдоцільніший метод калькулювання собівартості виготовлення продукції для хлібопекарських підприємств.

Аналіз останніх досліджень $і$ публікацій. Калькулювання собівартості виготовлення продукції - істотний чинник підвищення ефективності господарської ді-

Інформація про автора:

Дідик Андрій Зіновійович, аспірант, кафедра обліку і аудиту. Email: andriydz@gmail.com

Цитування за ДСту: Дідик А. З. Калькулювання собівартості продукції на хлібопекарських підприємствах України. Науковий вісник НЛТУ України. 2021, т. 31, № 4. С. 104-108.

Citation APA: Didyk, A. Z. (2021). Calculation of production costs at bakery enterprises of Ukraine. Scientific Bulletin of UNFU, 31(4), 104-108. https://doi.org/10.36930/40310417 
яльності як на рівні окремих хлібопекарських підприємств, так і в масштабах усієї країни. Це питання досліджено у працях багатьох вітчизняних учених-економістів, таких як: О. Байдик, Ф. Бутинець, О. Бутнік-Сіверський, Г. Краюхін, К. Ларіонов, С. Ніколаєва, Л. Нападовська, О. Орлов, С. Покропивний, Є. Рясних, Л. Хлапенов, М. Чумаченко, О. Горбач, С. Савченко. Питання особливостей калькулювання собівартості на хлібопекарських підприємствах порушено у роботах I. Павлюка, 3. Ельпінера, Т. Гуслякової. Але, незважаючи на великий науковий внесок українських вченихекономістів, багато проблемних питань калькулювання собівартості виготовлення продукції на хлібопекарських підприємствах потребують подальших досліджень, глибшого вивчення та створення нових підходів і способів їхнього удосконалення. Головна проблема полягає у недостатній обгрунтованості наявних методичних підходів до управління виробничими витратами відповідно до специфіки діяльності хлібопекарських підприємств. Процеси управління виробничими витратами на хлібопекарських підприємствах не мають належного рівня системності та динамічності. Саме незавершеність наукових досліджень 3 удосконалення управління виробничими витратами та калькулювання собівартості виготовлення продукції і очевидна практична важливість цієї проблеми зумовлює вибір та об'єктивний характер актуальності теми. Усі зазначені обставини доводять актуальність розкриття особливостей калькулювання собівартості виготовлення продукції на хлібопекарських підприємствах України.

Матеріали та методи дослідження. Теоретичним та методологічним підгрунтям дослідження $є$ фундаментальні надбання сучасного бухгалтерського обліку, доробок вітчизняних учених щодо деяких аспектів організації і ведення обліку виробничих витрат та калькулювання собівартості виготовлення продукції. Аналіз цієї проблеми здійснено за допомогою таких методів: системний аналіз - для деталізації і розчленування об'єкта дослідження на окремі важливі складові елементи; синтез - для узагальнення різних аспектів обліку виробничих витрат; конкретизація - для обгрунтування змісту форм облікового забезпечення; статистичні й аналітичні розрахунки, порівняння - для зіставлення особливостей різних методів калькулювання; групування - для визначення залежності показників один від одного.

\section{Результати дослідження та їх обговорення / Research results and their discussion}

За умов ринкової економіки успішна робота усіх промислових підприємств, і хлібопекарських підприємств зокрема, істотно залежить від правильно вибраної системи обліку виробничих витрат. Від того, як точно і своєчасно вони відображаються в бухгалтерському обліку, залежить точність та достовірність фінансового результату, який отримує підприємство.

Одним 3 найефективніших методів управління витратами $\epsilon$ калькулювання собівартості виготовлення продукції - процес визначення собівартості виготовлення продукції, який полягає в акумулюванні затрат на виробництво і віднесення їх на готовий продукт. Це пояснюють відносною простотою розрахунків, що робить цей метод доступним навіть для не надто кваліфікованих працівників на хлібопекарських підприємствах. Калькулювання собівартості одиниці продукції (робіт, послуг) здійснюють для визначення ефективності запланованих і фактично здійснених технологічних, організаційних та економічних заходів, спрямованих на розвиток і вдосконалення виробництва і для обгрунтування цінової політики підприємства [3]. Калькулювання собівартості досить легко автоматизувати. Сучасні бухгалтерські програми дають змогу отримати дані про собівартість та рентабельність кожного виду продукції в режимі реального часу. Цей чинник особливо актуальний для підприємств із широким асортиментом продукції.

Для забезпечення належного управління виробничими витратами необхідне економічно обгрунтоване групування витрат, створення умов для правильного розподілу виробничих витрат. Собівартість виготовлення продукції розраховують за статтями витрат, які $є$ калькуляційними елементами. Статті витрат відрізняються на різних підприємствах і залежать від потреб управління. На хлібопекарських підприємствах $є$ певні особливості в побудові статей калькуляції. Наприклад, статтю витрат за типовою номенклатурою називають "Сировина і матеріали", а на хлібопекарському підприємстві "Витрати на підставну сировину". На практиці самостійними статтями часто виділяють "Пакувальні матеріали", "Інша сировина для хлібопечення" тощо.

За сучасних умов господарювання для хлібопекарських підприємств можуть застосовуватися різні методи обліку витрат на виробництво і калькулювання собівартості виготовлення продукції [1]. Основні методи наведено на рисунку.

Методи калькулювання собівартості продукції

Простий Позамовний Попередільний Нормативний

Рисунок. Класифікація методів калькулювання собівартості виготовлення продукції / Classification of methods of calculating the production cost

Простий (однопередільний) метод обліку витрат і калькулювання собівартості виготовлення продукції застосовуються у виробництвах, які виготовляють тільки один вид продукції за допомогою короткого виробничого циклу. Суть цього методу полягає в тому, що фактичну собівартість одиниці продукції визначають шляхом ділення суми витрат виробництва на фактичну кількість виготовленої продукції. До підприємств, що використовують однопередільний метод витрат і калькулювання собівартості, належать електростанції, лісозаготівельні та інші виробництва. Хлібопекарські підприємства не можуть використовувати цей метод через наявність широкої номенклатури виробництва.

Об'єктом калькуляції позамовного методу є виробниче замовлення. Воно відкривається на частину виробу чи невеликий обсяг виробів, одну роботу чи послугу. Виробничі витрати обліковують за такими замовленнями. Отже, цей метод не надто підходить для хлібопекарських підприємств, які щоденно виробляють велику кількість однорідної продукції, а також через відсутність оперативного контролю за рівнем витрат, складність і громіздкість інвентаризації незавершеного виробництва. Його можна застосовувати на підприємствах, що виготовляють одиничні або дрібні партії виробів одного виду, для виготовлення унікального виробу. Прикладами позамовного виробництва $є$ підприємства машинобудування, суднобудування, літакобудування, наукомісткі та інтелектуальні послуги, меблева промисловість, будівництво. 
У разі використання попередільного методу процес випуску готової продукції складається з кількох послідовних технологічно завершених переділів, у кожному 3 яких розраховують собівартість виготовлення продукції. Враховуючи, що напівфабрикати можуть бути реалізовані, їхню собівартість також розраховують. Об'єктом калькуляції є вид або група продукції кожного переділу. Отже, цей метод обліку найчастіше використовують на підприємствах та у виробництвах 3 повторюваною й однорідною масовою продукцією. Продукцію виготовляють в умовах однорідного і безперервного технологічного процесу. Прикладами використання попередільного методу є хімічна і нафтопереробна промисловість, текстильна, цементна, харчова, целюлознопаперова, скляна промисловість. Цей метод можна застосовувати на хлібопекарських підприємствах, проте в нього є недоліки. Попередільний метод - єдиний метод калькуляції, при якому принципово неможливий аналітичний облік витрат на виробництво за об'єктами калькуляції. Також, для організації роздільного обліку витрат за кожним переділом до рахунка обліку 23 "Виробництво" потрібно відкрити окремий субрахунок.

Одним 3 найоптимальніших для хлібопекарських підприємств можна вважати метод обліку витрат на виробництво за підрозділами з елементами нормативного. Відповідно до Я. М. Голубки, "нормативні калькуляції являють собою визначення собівартості одиниці продукції за статтями витрат у грошовому вираженні на підставі чинних норм витрат матеріалів, заробітної плати тощо. Чинні норми розробляють на кожен вид виробу за досягнутим підприємством рівнем технології, організації виробництва. Ці норми використовують для безпосереднього відпуску матеріалів на виробничі потреби і нарахування заробітної плати" [1]. Фактичні витрати за цим методом відображаються окремо у частці витрат по нормах і в частці витрат, що $є$ відхиленням від норм за допомогою щоденного документування витрат. Не відображені в обліку відхилення встановлюють під час здійснення інвентаризації незавершеного виробництва. Варто зауважити, що відхиленням від норм вважають не тільки перевитрати, а й економію матеріальних і трудових ресурсів. При цьому понаднормативні прямі витрати не містять у виробничу собівартість виготовлення продукції, а відносять до складу собівартості реалізованої продукції [5].

Важливою складовою частиною нормативного методу, відповідно до Т. Г. Нікульникової, є "система норм матеріальних затрат, яка містить сукупність норм витрат матеріалів на підставні та допоміжні виробництва, ремонт, обслуговування й експлуатацію основних засобів. Норми витрат сировини та основних матеріалів 3 урахуванням гранично припустимих витрат беруть за да- ними продуктового розрахунку. Вартість основних матеріалів визначають за допомогою цін придбання" [4].

Калькулювання нормативних витрат охоплює кілька етапів:

- установлення нормативів витрат;

- нагромадження даних про фактичні витрати;

- аналіз відхилень і складання звітності;

- дослідження причин відхилень;

- зміни нормативних витрат (установлення нових стандартів), якщо у цьому є потреба [2].

Потребу підприємства в сировині за рік розраховують на підставі даних про середньодобову потребу сировини, яка перемножується на 330 днів (кількість робочих днів на рік). Доставка становить близько 10 \% від вартості сировини.

Для розрахунку фактичної собівартості виробленої продукції після завершення звітного періоду використовують звітну калькуляцію. Ї̈̈ особливістю $є$ те, що в такій калькуляції відображають у тому числі й втрати, що не передбачені в розрахунку планової вартості (витрати, пов'язані з відхиленням від встановленого технологічного процесу, перевищення норм браку тощо).

Варто зазначити, що для порівняння планових і фактичних показників під час планування й обліку потрібно використовувати однакові об'єкти та одиниці калькулювання, однакові методи розподілу та групування витрат, однакові системи нормативів витрат за всією номенклатурою виробів, які виготовляє хлібопекарське підприємство (табл. 1).

Аналіз структури виробничих витрат за економічними елементами потрібно доповнювати вивченням динаміки окремих статей калькуляції фактично випущеної товарної продукції за попередні періоди. При цьому для забезпечення порівнянності даних потрібно порівнювати фактичну собівартість однієї і тієї самої реально випущеної продукції у звітних періодах (табл. 2).

3 таблиць видно, що найбільшу питому вагу у виробничих витратах займають сировина і матеріали. Причому фактична частка сировини і матеріалів за 2020 рік $(50,4 \%)$ на $3,1 \%$ перевищує їх запланований рівень $(47,3 \%)$ і на $0,9 \%$ показник 2018 року $(49,5 \%)$. Це може бути пов'язано як з підвищенням цін на матеріальні ресурси, так і з нераціональним використанням сировини і матеріалів, їх необгрунтованими замінами або зміною запланованої структури випуску продукції.

У будь-якому разі найбільша питома вага цього елемента зумовлює потреба пошуку резервів зниження витрат на сировину і матеріали. При цьому для створення обгрунтованих рекомендацій 3 економії сировини аналіз показників потрібно доповнювати глибоким вивченням даних аналітичного бухгалтерського обліку та калькуляцій собівартості окремих виробів.

Табл. 1. Структура витрат на виробництво продукції ПрАТ "Концерн Хлібпром" у 2020 р. (млн грн)* / Structure of production costs of Concern Khlibprom PJSC in 2020 (UAH million)*

\begin{tabular}{|l|c|c|c|c|c|}
\hline \multicolumn{2}{|c|}{ Статті калькуляції } & \multicolumn{2}{c|}{ Витрати } & \multicolumn{3}{c|}{ Структура витрат, \% } \\
\cline { 2 - 7 } & План & Факт & План & Факт & Відхилення \\
\hline Сировина і матеріали за відрахуванням відходів & 1148 & 1355 & 47,3 & 50,4 & 3,1 \\
\hline Напівфабрикати & 685 & 765 & 28,2 & 28,4 & 0,2 \\
\hline Допоміжні матеріали & 17 & 18 & 0,7 & 0,7 & 0,0 \\
\hline Паливо та енергія на технологічні цілі & 15 & 14 & 0,6 & 0,5 & $-0,1$ \\
\hline Оплата праці та відрахування єдиного соціального внеску & 320 & 334 & 13,2 & 12,4 & $-0,8$ \\
\hline Амортизація основних фондів & 170 & 160 & 7,0 & 5,9 & $-1,1$ \\
\hline Інші витрати & 71 & 45 & 2,9 & 1,7 & $-1,2$ \\
\hline Разом витрат & 2426 & 2691 & 100,0 & 100,0 & 0,0 \\
\hline
\end{tabular}

Джерело: *авторська розробка на підставі регістрів обліку ПрАТ "Концерн Хлібпром". 
Табл. 2. Динаміка статей калькуляції ПрАТ "Концерн Хлібпром" за 2018-2020 роки (млн грн)* / Dynamics of costing articles of Concern Khlibprom PJSC for 2018-2020 (UAH million)*

\begin{tabular}{|l|c|c|c|c|c|c|c|}
\hline \multicolumn{1}{|c|}{ Статті калькуляціï } & \multicolumn{3}{|c|}{ Фактичні витрати } & \multicolumn{5}{c|}{ Структура витрат, \% } \\
\cline { 2 - 9 } & 2018 & 2019 & 2020 & 2018 & 2019 & 2020 & $\begin{array}{c}2020 \text { до } \\
2018\end{array}$ \\
\hline Сировина і матеріали за відрахуванням відходів & 1351 & 1483 & 1355 & 49,5 & 48,7 & 50,4 & 0,9 \\
\hline Напівфабрикати & 734 & 851 & 765 & 26,9 & 27,9 & 28,4 & 1,5 \\
\hline Допоміжні матеріали & 18 & 15 & 18 & 0,7 & 0,5 & 0,7 & 0,0 \\
\hline Паливо та енергія на технологічні цілі & 14 & 20 & 14 & 0,5 & 0,7 & 0,5 & 0,0 \\
\hline $\begin{array}{l}\text { Оплата праці та відрахування єдиного соціально- } \\
\text { го внеску }\end{array}$ & 342 & 323 & 334 & 12,5 & 10,6 & 12,4 & $-0,1$ \\
\hline Амортизація основних фондів & 197 & 277 & 160 & 7,2 & 9,1 & 5,9 & $-1,3$ \\
\hline Інші витрати & 73 & 79 & 45 & 2,7 & 2,6 & 1,7 & $-1,0$ \\
\hline Разом витрат & 2729 & 3048 & 2691 & 100,0 & 100,0 & 100,0 & 0,0 \\
\hline
\end{tabular}

Джерело: *авторська розробка на підставі регістрів обліку ПрАТ "Концерн Хлібпром".

У поєднанні із виявленим зниженням частки витрат на оплату праці $(-0,8 \%)$, зростання частки витрат на сировину часто свідчить про підвищення продуктивності праці. Проте зниження питомої ваги заробітної плати може спричинятися і зміною структури продукції та випуском менш трудомістких виробів. I варто зауважити, що порівняно з попередніми періодами ії частка практично не змінилася.

Збільшення питомої ваги амортизації часто $\epsilon$ наслідком підвищення технічної оснащеності виробництва. Але під час аналізу виявлено зниження частки амортизації і порівняно з планом $(-1,1 \%)$, і з попередніми показниками $(-1,3)$, причинами якого можуть бути як зниження фондоозброєності внаслідок вибуття застарілого обладнання і невикористовуваних площ, так і через негативні процеси втрати виробничих потужностей.

Також у ПрАТ "Концерн Хлібпром" відзначено зменшення питомої ваги інших витрат на 1,2 і $1 \%$ порівняно $з$ плановими і фактичними показниками відповідно. Це може бути зумовлено, в тому числі, зменшенням витрат $з$ послуг невиробничого характеру сторонніх організацій, стороннього транспорту, орендної плати за користування основними засобами.

Окремо потрібно зазначити різке зниження загального обсягу витрат у 2020 р. порівняно 3 попереднім (357 млн). Найімовірнішою причиною можна вважати зменшення обсягу виробництва продукції через карантинні обмеження.

\section{Висновки / Conclusions}

Встановлено, що калькулювання собівартості виготовлення продукції - це система розрахунків, яка допомагає визначити собівартість проданої продукції та її частин, конкретних видів виробів, суму витрат окремих підрозділів підприємства. Собівартість виготовлення продукції розраховують за статтями витрат, які є калькуляційними елементами.

Основними методами калькулювання $є$ однопередільний, позамовний, попередільний і нормативний. Однопередільний метод не може використовуватися на хлібопекарських підприємствах через наявність широкої номенклатури виробництва. Недоліками позамовного методу є відсутність оперативного контролю за рівнем витрат, складність і громіздкість інвентаризації незавершеного виробництва. А в разі використання попередільного методу неможливий аналітичний облік витрат на виробництво за об'єктами калькуляції.

Найоптимальнішим для використання на хлібопекарських підприємствах можна вважати нормативний метод. Його суть полягає у визначенні собівартості одиниці продукції за статтями витрат у грошовому вираженні на підставі чинних норм витрат матеріалів, заробітної плати тощо. Фактичні витрати відображаються окремо у частці витрат за нормами і в частці витрат, що $\epsilon$ відхиленням від норм за допомогою щоденного документування витрат.

Перспективою подальших досліджень є аналіз процесу управління виробничими витратами під час калькулювання собівартості виготовлення продукції хлібопекарських підприємств і недопущення перевитрат виробничих ресурсів.

\section{References}

1. Holubka, Y. V., \& Marton, K. Y. (2014). Method of accounting expenses and calculation of production costs at bakeries. Naukovyi visnyk Mukachivskoho derzhavnoho universytetu Ekonomichni nauky, 17(12), 114-120. [In Ukrainian].

2. Korolova, O. I. (2015). Problems and development prospects of production costs accounting. Ekonomika ta upravlinnia na transporti, 1, 79-90. [In Ukrainian].

3. Melnychuk, Y. P. (2016). Calculation of the cost of organic crop production. Ekonomika ta derzhava, 2, 87-90. [In Ukrainian].

4. Nikulnykova, T. H., \& Mezentseva, N. M. (2015). The formation of direct material costs in the prime cost of bakery and dairy products of Kryvyi Rih enterprises in 2013. Naukovyi visnyk Khersonskoho derzhavnoho universytetu, 10(3), 195-199. [In Ukrainian].

5. Polozhennia. (1999). Polozhennia (standart) bukhhalterskoho obliku 16 "Vytraty", zatverdzhene nakazom Ministerstva finansiv Ukrainy vid 31 hrudnia 1999, No. 318 (zi zminamy i dopovnenniamy). Retrieved from: https://zakon.rada.gov.ua/go/z0027-00

\section{A. Z. Didyk \\ Ivan Franko National University of Lviv, Lviv, Ukraine}

\section{CALCULATION OF PRODUCTION COSTS AT BAKERY ENTERPRISES OF UKRAINE}

The process of management of the bakery enterprises is considerably complicated in the conditions of market relations. The effectiveness of production management depends on the level of information support of managers. The production cost as an economic category depends on the costs incurred and the number of manufactured products, and also the methods of determining it. The calculation of the cost is crucial in the process of economic activity. The following methods were used to conduct this study: analysis - to divide the subject of organization of accounting by stages and the direction of their study within a single accounting 
process; synthesis - to summarize various aspects of accounting; grouping - to determine the dependence of indicators on each other; specification - to justify the content of forms of accounting; analytical and statistical calculations; comparisons - to compare data in dynamics. The article considers the peculiarities of calculating the production cost at bakery enterprises of Ukraine. The study determines the content of calculating the cost of production and considers the peculiarities of the construction of cost articles at bakery enterprises. The article considers the shortcomings of different methods of calculating the production cost, which include single-order, out-of-order, preliminary and regulatory. The main disadvantage of these methods is the use of calculation objects that cannot be applied at bakery enterprises. The normative method can be considered the most optimal for use at the bakery enterprises. The main objectives of this method are the operational analysis of production costs and prevention of misuse of resources. The article also identifies the stages of calculation of regulatory costs and studies the peculiarities of their use at bakery enterprises of Ukraine. The author identifies problems in calculating the needs of the enterprise in raw materials. In addition, he substantiated the value of the reporting calculation to calculate the actual cost of production. So, given the fact that the cost of production directly affects the profits of the enterprise, the issue of ensuring the optimal level of costs comes to the fore. This can be achieved only with a wellestablished system of calculating the production cost.

Keywords: normative method; calculation; production cost; cost item; actual costs; regulatory costs. 